\title{
DAMPAK DISIPLIN KERJA TERHADAP KEMAMPUAN KINERJA APARATUR NAGARI DALAM PENGELOLAAN KEUANGAN NAGARI DI KECAMATAN BANUHAMPU DAN SUNGAI PUA
}

\author{
Rahmi Yanti \\ Jurusan Administrasi Publik, Fakultas Ilmu Sosial, Universitas Negeri Padang \\ Email: rahmiyanti888@gmail.com
}

\begin{abstract}
The purpose of this study was to analyze the impact of work discipline on the performance capabilities of the nagari apparatus in nagari financial management in Banuhampu and Sungai Pua Subdistricts. The population used in this study were all nagari apparatus in Banuhampu and Sungai Pua Subdistricts consisted of 80 people, while the samples used as many as 75 respondents that were determined by the Slovin formula using the proportionate stratified random sampling technique. Data in this study were collected using questionnaires with Likert scale measurement and analyzed with multiple linear regression test. The results of this study indicated that the work discipline of the nagari apparatus was relatively high while the performance of the nagari apparatus was still low. Besides, the results of the regression test explained that work discipline had an impact on the performance capabilities of the nagari apparatus in nagari financial management in Banuhampu and Sungai Pua Districts.
\end{abstract}

Keywords: Work discipline, work performance, nagari financial management

Submitted: 22 March 2019

Reviewed: 6 April 2019

Published: 29 April 2019

How to Cite: Rahmi Yanti. 2019. Dampak Disiplin Kerja Terhadap Kemampuan Kinerja Aparatur Nagari dalam Pengelolan Keuangan Nagari di Kecamatan Banuhampu dan Sungai Pua. 3(1): pp.79-90, DOI: https://doi.org/10.24036/jess/vol3-iss

\section{Pendahuluan}

Sistem pemerintahan desentralisasi sebagai sistem pemerintahan yang membagi kekuasaan dari pemerintah pusat kepada pemerintah daerah (K. Permatasari et al, 2013). Undang-Undang Dasar 1945 menjelaskan pemerintah pusat memberikan keleluasaan kepada daerah untuk menyelenggarakan otonomi daerah. Otonomi daerah menurut Undang-Undang Nomor 23 Tahun 2014 tentang pemerintahan daerah adalah hak, wewenang dan kewajiban daerah otonom untuk mengatur dan mengurus sendiri urusan pemerintahan dan kepentingan masyarakat setempat sesuai dengan peraturan perundang-undangan, juga dijelaskan bahwa tugas pemerintahan daerah yang semakin berat sehingga harus dilimpahkan kepada daerah-daerah di bawahnya dalam hal ini adalah pemerintahan desa. Dalam Undang-Undang Nomor 32 Tahun 2004 tentang pemerintahan daerah, desa atau yang disebut dengan nama lain seperti nagari di Sumatra Barat, desa adalah kesatuan masyarakat hukum yang memiliki batas-batas wilayah yang berwenang untuk mengatur dan mengurus kepentingan masyarakat setempat, berdasarkan 
asal-usul dan adat istiadat setempat yang diakui dan dihormati dalam sistem Pemerintahan Negara Kesatuan Republik Indonesia.

Sesuai asas desentralisasi dalam otonomi daerah dilaksanakanlah program dana desa. Program dana desa dilaksanakan sejak tahun 2014, merupakan bagian dari APBN yang di peruntukkan bagi desa ditransfer melalui APBD Kabupaten /Kota. Berdasarkan Undang-Undang Nomor 6 Tahun 2014 Tentang Desa tujuan dana desa diantaranya meningkatkan pelayanan publik di desa, mengentaskan kemiskinan, memajukan perekonomian desa, mengatasi kesenjangan pembangunan antar desa, dan memperkuat masyarakat desa sebagai subjek dari pembangunan, namun lebih di prioritaskan kepada pelayanan dan pembangunan. Sesuai asas otonomi Undang-Undang Nomor 23 Tahun 2014 dalam pelaksanaannya pemerintah daerah berwenang untuk mengelola dan memanfaatkan dana desa sesuai dengan kepentingan umum demi kesejateraan masyarakat, dan pengelolaan keuangan nagari harus di kelola secara baik dan benar.

Nagari sebagai sebuah organisasi pasti memiliki tujuan, dimana proses dalam pencapaian tujuan tergantung pada bagaimana memanfaatkan sumber daya yang ada dalam organisasi tersebut terutama sumber daya manusia yang ada di dalamnya. Veithsal dalam (Azhari \& Syamsir, 2012) bahwa organisasi adalah wadah yang memungkinkan seseorang dapat meraih hasil atau tujuan yang sebelumnya tidak dapat dicapai secara sendiri-sendiri, dengan kata lain organisasi merupakan suatu bentuk kelompok individu yang melakukan kerjasama guna mencapai tujuan tertentu dan pencapaian tujuan tersebut tidak terlepas dari peran orang-orang yang ada dalam organisasi yang bersangkutan. Selain itu Sumber daya manusia salah satu sumber daya terpenting pada setiap organisasi, terutama dalam pengelolaan keuangan nagari, hal ini dikarenakan manusia sebagai penggerak dan pengelola sumber-sumber daya lainnya. Seringnya kegagalan sebuah organisasi disebabkan karena sumber daya manusia yang ada di dalamnya tidak dikelola dengan benar, sehingga perlu adanya tata kelola sumber daya manusia dalam organisasi agar kinerja yang di hasilkan mampu mewujudkan tujuan organisasi, salah satunya disiplin kerja.

Disiplin kerja bagian dari sumber daya manusia yang merupakan salah satu faktor terpenting dalam meningkatkan kinerja pegawai. Mailiana (2016) mengatakan bahwa seorang pegawai yang mempunyai tingkat kedisiplinan tinggi akan tetap bekerja dengan baik walaupun tanpa diawasi oleh atasan. Seorang pegawai yang disiplin, tidak akan mencuri waktu kerja untuk melakukan hal lain yang tidak ada kaitannya dengan pekerjaan. Demikian juga pegawai yang mempunyai kedisiplinan akan mentaati peraturan yang ada dalam lingkungan kerja dengan kesadaran yang tinggi tanpa ada rasa paksaan. Pada akhirnya pegawai yang mempunyai kedisiplinan kerja yang tinggi akan mempunyai kinerja yang baik karena waktu kerja dimanfaatkannya sebaik mungkin untuk melaksanakan pekerjaan sesuai dengan target yang telah ditetapkan. Bila para pegawai/karyawan memiliki disiplin kerja yang tinggi, diharapkan akan mampu menyelesaikan tugas dengan cepat dan tepat sehingga akan meningkatkan motivasi kerjanya yang mempengaruhi tingkat kinerja. selain itu Putra et al., (2016) juga menjelaskan agar aktifitas yang ingin dilaksankan terlaksana dengan 
semestinya sesuai aturan yang telah ditetapkan maka diperlukan disiplin kerja, karena disiplin kerja mempengaruhi kinerja. Sedangkan menurut Leiden (dalam Putra et al., 2016) menyatakan untuk mengatasi masalah kinerja yang buruk perlu diterapkannya disiplin kerja dengan baik karena disiplin kerja dapat memperkuat pengaruh prilaku kerja seseorang dalam kelompok atau organisasi

Berdasarkan hasil wawancara yang dilakukan pada hari senin tanggal 10 September 2018 dengan Bapak Wali Nagari Batagak Kecamatan Sungai Pua yaitu Hendri Dunan, dapat dipahami bahwa disiplin kerja aparatur nagari telah diatur dengan Peraturan Bupati Kabupaten Agam No 17 Tahun 2017 tentang Disiplin Kerja Aparatur Pemerintahan Nagari. Namun dalam pelaksanaanya Hendri Dunan mengatakan bahwa di kantor wali nagari ini tidak terlalu terikat dengan aturan yang ada. Hal ini dikarenakan adanya urusan lain aparatur nagari di luar urusan sebagai aparatur nagari, sehingga berakibat pada keterlambatan aparatur nagari ke kantor ataupun keluar pada saat jam kerja.

Berkaitan teori dan masalah yang dikemukakan diatas, dari hasil penelitian Pangarso \& Susanti (2016) dan penelitian Mailiana (2016) tentang pengaruh disiplin kerja terhadap kinerja, hasil penelitiannya menyatakan bahwa disiplin kerja mempunyai pengaruh yang signifikan terhadap kinerja pegawai. Sedangkan hasil penelitian Arianto (2013) menyatakan bahwa kedisiplinan kerja tidak berpengaruh terhadap kinerja. Dari penjelasan diatas dapat diketahui masih terdapat hasil penelitian yang berbeda dengan variabel yang sama.

Berdasarkan masalah yang dipaparkan pada latar belakang, bahwa penulis tertarik melaksanakan penelitian di Kecamatan Banuhampu dan Sungai Pua. Penelitian ini merupakan intisari dari hasil penelitian skripsi serta merupakan bagian dari penelitian payung dari Syamsir (2017) yang berjudul Model Pembinaan Aparatur Pemerintahan Nagari dalam Pengelolaan Keuangan Nagari di Kabupaten Tanah Datar. Serta yang menjadi rumusan masalah dalam penelitian ini adalahapakah terdapat dampakdisiplin kerja (yang mencakup dua sub variabel aturan kerja dan etika kerja) terhadap kemampuan kinerja aparatur nagari dalam pengelolaan keuangan nagari di Kecamatan Banuhampu dan Sungai Pua?

\section{Tinjauan Kepustakaan}

\section{Disiplin kerja dan kinerja}

Hasibuan (2010) menjelaskan kedisiplinan adalah kesadaran dan kesediaan seseorang menaati semua peraturan perusahaan dan norma-norma social yang berlaku. Sedangkan kesadaran adalah sikap seseorang yang secara sukarela menaati semua peraturan dan sadar akan tugas dan tanggung jawab. Kesediaan sebagai suatu sikap, tingkah laku dan perbuatan seseorang yang sesuai dengan peraturan perusahaan baik tertulis maupun tidak tertulis. Menurut Putra et al (2016) disiplin kerja adalah bentuk dari ketaatan terhadap peraturan tata tertib yang ditetapkan. Zesbendri dan Aryanti dalam (Putra et al., 2016) menjelaskan bahwa modal utama yang dapat mempengaruhi kinerja karyawan adalah disiplin. Sedangkan menurut J. A. Permatasari \& Mayowan (2015) disiplin kerja merupakan kesediaan karyawan untuk menaati aturan dan norma-norma yang 
berlaku di dalam perusahaan baik itu aturan yang tertulis ataupun aturan yang tidak tertulis. Dapat disimpulkan bahwa disiplin kerja mampu mempengaruhi kinerja pegawai dalam suatu organisasi dikarenakan disiplin kerja mampu mengontrol tata kerja pegawai agar bersungguh sungguh bekerja dan bekerja harus sesuai dengan aturan yang telah ditetapkan.

Anwar (2001) mengatakan yang mempengaruhi tingkat kedisiplinan karyawan dalam suatu organisasi adalah: tujuan dan kemampuan, teladan kepemimpinan, balas jasa, keadilan, waskat (pengawasan melekat), sanksi dan hukuman, ketegasan, serta hubungan kemenusiaan. Putra et al (2016) menyimpulkan bahwa dimensi yang digunakan untuk mengukur disiplin kerja adalah: aturan kerja yang terdiri dari indikator tingkat kehadiran, ketentuan jam kerja, dan intruksi dari atasan; kemudian etika kerja yang terdiri dari indikator tingkah laku karyawan terhadap atasan dan rekan kerja, kejujuran karyawan dalam bekerja, dan tanggungjawab karyawan terhadap pekerjaan.

Selanjutnya Edison dkk dalam (Baiyulis et al, 2018) mengatakan kinerja adalah hasil pencapaian dari suatu proses yang mengacu dan diukur selama periode waktu tertentu berdasarkan ketentuan atau indikator-indikator kesepakatan yang telah ditetapkan sebelumnya, juga dijelaskan bahwa kinerja merupakan kunci efektif atau tidaknya suatu organisasi. Sedangkan Marwansyah dalam (Fatmaliza, Syamsir, \& Jumiati, 2018) mengemukakan bahwa kinerja adalah capaian prestasi seseorang yang berhubungan dengan tugas-tugas yang harus diselesaikannya. Mulyadi (2015) kinerja (prestasi kerja) di definisikan sebagai hasil kerja yang dicapai oleh pekerja atau karyawan secara kualitas dan kuantitas yang ditetapkan sesuai dengan tugas dan tanggung jawab mereka. Dapat disimpulkan bahwa kinerja merupakan hasil atau pencapaian dari proses yang di lakukan pekerja sesuai dengan tugas dan tanggung jawab yang di emban.

Sedangkan Davis (dalam Mulyadi, 2015) faktor-faktor yang mempengaruhi kinerja yaitu kemampuan, motivasi, dan sikap mental. John Miner (dalam Edison, 2015) ada dimensi yang menjadi tolak ukur untuk mencapai atau melakukan penilaian kinerja yaitu: Kualitas, seperti tingkat kesalahan, kerusakan dan kecermatan, kuantitas, yaitu jumlah pekerjaan yang di hasilkan; Penggunaan waktu dalam kerja, seperti ketidakhadiran, keterlambatan, waktu kerja efektif/ jam kerja hilang, kerjasama dengan orang lain dalam bekerja.

Terkait dengan hubungan disiplin kerja dengan kinerja, Putra et al (2016) mengatakan bahwa disiplin kerja salah satu aspek yang mempengaruhi kinerja karyawan, dimana kedisiplinan diperlukan agar seluruh aktivitas yang sedang dan akan dilaksanakan berjalan sesuai mekanisme yang ditentukan. Kemudian menurut Leiden (dalam Putra et al, 2016) menyatakan bahwa dengan ditegakkannya disiplin kerja maka dapat mengatasi masalah kinerja yang buruk serta memperkuat pengaruh prilaku kerja karyawan dalam kelompok dan organisasi. Sedangkan menurut (Oktaviani, 2018) bahwa banyak faktor yang mempengaruhi kinerja pegawai salah satunya adalah disiplin pegawai.

Banyak penelitian dilakukan untuk melihat dampak disiplin kerja terhadap kinerja dalam sebuah organisasi. Diantara penelitian yang telah dilakukan ditemukan hasil yang menyatakan bahwa disiplin kerja memberikan dampak terhadap kinerja seseorang atau kelompok. Seperti penelitian yang dilakukan oleh 
Pangarso \& Susanti, (2016), Mailiana (2016), Husain (2018) dan (Liyas \& Primadi, 2017). Sedangkan penelitian yang dilakukan Arianto (2013) menyatakan disiplin kerja tidak berdampak terhadap kinerja.

\section{Pengelolaan Keuangan Desa/Nagari dan Indikator Pengukur Kinerja dalam Pengelolaan Keuangan Nagari}

Keuangan nagari merupakan bagian dari keuangan daerah. Menurut Abdul Halim (dalam Putera 2016) menjelaskan bahwa keuangan daerah adalah kekayaan daerah yang bernilai,baik uang maupun barang sepanjang tidak dikuasai oleh daerah yang lebih tinggi sebagai hak dan kewajiban dari daerah tersebut.

Berdasarkan Peraturan Menteri Dalam Negeri Republik Indonesia Nomor 113 tahun 2014 Tentang Pengelolaan Keuangan Desa, bahwa pengelolaan keuangan desa merupakan kegitan yang berproses mulai dari perencanaan, pelaksanaan penatausahaan, pelaporan dan pertanggungjawaban keuangan desa. Serta dijelaskan bahwa yang berkuasan dan berwenang atas pengelolaan keuangan desa adalah kepala desa atau semacamnya dan perangkat desa atau disebut pelaksana teknis pengelolaan keuangan desa (PTPKD) yang nantinya membantu kepada desa dalam proses kegiatan pengelolaan keuangan desa atau disebut dengan aparatur nagari.

Berdasarkan Peraturan Pemerintah Nomor 47 Tahun 2015 tentang Peraturan Pelaksanaan Undang-Undang Nomor 6 Tahun 2014 Tentang Desa pasal 1 ayat 8 yang dimaksud dengan dana desa adalah bagian dari APBN yang ditransfer kepada APBD Kabupaten/Kota serta diperuntukkan kepada desa untuk membiayai kegiatan pemerintahan yang berkaitan dengan penyelenggaraan pemerintahan, pelaksanaa pembangunan, pembinaan masyarakat serta pemberdayaan masyarakat.

Dalam BPKP (2015) dijelaskan bahwa asas-asas pengelolaan keuangan desa sesuai Permendagri Nomor 113 Tahun 2014 terdiri dari: pertama transparan sebagai bentuk dari keterbukaan kepada masyarakat agar masyarakat mendapatkan informasi yang seluas-luasnya terkait dengan keuangan desa, serta maksud transparan yang diinginkan adalah informasi yang dibenarkan benar adanya, jujur serta tidak deskriminatif dalam penyelenggaraan pemerintahan desa tetap berlandaskan pada aruran perundangan yang berlaku; kedua akuntabel berarti dari kegiatan yang dilaksanakan hingga hasil akhir dari pengelolaan keuangan desa dapat dipertanggungjawabkan kepada publik. Ketiga partisipatif maksudnya adalah penyelenggaraan pemerintahan desa mengikutsertakan kelembagaan desa dan unsur masyarakat desa, dan keempat tertib dan disiplin anggaran yaitu pengelolaan keuangan desa harus mengacu pada aturan atau pedoman yang melandasinya.

\section{Metode Penelitian}

Penelitian yang dilakukan bersifat kuantitatif deskriptif asosiatif untuk melihat dampak disiplin kerja terkait aturan kerja dan etika kerja terhadap kemampuan kinerja aparatur nagari dalam pengelolaan keuangan nagari di Kecamatan Banuhampu dan Sungai Pua. Populasi yang digunakan dalam penelitian ini adalah 
seluruh aparatur nagari yang ada pada seluruh nagari di Kecamatan Banuhampu dan Sungai Pua. Dengan menggunakan rumus Slovin menggunakan teknik proportionate stratified random sampling diperoleh sampel yang digunakan sebanyak 75 responden.

Data dalam penelitian ini dikumpulkan melalui penyebaran angket kepada responden dengan 4 opsi jawaban berdasarkan pengukuran menggunakan skala Likert yang terdiri dari (sangat setuju, setuju, kurang setuju, dan tidak setuju). Kemudian analisis data dilakukan dengan teknik deskriptif. Sebelum angket digunakan terlebih dahulu dilakukan uji validitas dan reabilitas. Selain itu untuk mendapatkan gambaran umum tentang kedua variable juga digunakan frekuensi, mean, dan TCR (Tingkat Capaian Responden). Teknik analisis data dalam penelitian ini adalah dengan menggunakan analisis regresi linear berganda, yang selanjutnya dilakukan uji hipotesis.

\section{Hasil Temuan serta Penjelasan}

\section{Temuan Penelitian}

Secara umum hasil penelitian menunjukkan rata-rata TCR skor variabel disiplin kerjaaparatur nagari, tergambar pada tabel berikut ini:

Tabel 1. Deskripsi Variabel Disiplin Kerja

\begin{tabular}{lcccc}
\hline \multirow{2}{*}{ Sub variabel } & \multirow{2}{*}{ N } & Mean/TCR & \multicolumn{2}{c}{$\begin{array}{c}\text { Kategori mean } \\
\text { responden }\end{array}$} \\
\cline { 4 - 5 } & & & Tinggi & Rendah \\
\hline Rata- rata aturan kerja & 75 & $3,19 / 79,78 \%$ & $31 / 41 \%$ & $44 / 59 \%$ \\
Rata-rata etika kerja & 75 & $3,46 / 86,44 \%$ & $36 / 48 \%$ & $39 / 52 \%$ \\
\hline Rata-rata variabel disiplin kerja & $\mathbf{6 1}$ & $\mathbf{3 , 3 2 / 8 3 , 1 1 \%}$ & $\mathbf{3 8} / \mathbf{5 1 \%} \%$ & $\mathbf{3 7 / 4 9 \%}$ \\
\hline
\end{tabular}

Tabel 1 di atas menjelaskan bahwa rata-rata TCR sub variabel aturan kerja aparatur nagari berada pada kategori "Tinggi" (79,78\%). Selanjutnya bila dilihat dari kategori mean responden, maka dapat dijelaskan bahwa aparatur nagari yang mematuhi aturan kerja berada di bawah rata-rata (mean) lebih besar dibanding mereka yang mematuhi aturan kerja di atas rata-rata dengan perbandingan 59\%:341\%. Sehingga dapat disimpulkan bahwa aparatur nagari yang mematuhi aturan kerja masih tergolong rendah dalam pengelolaan keuangan nagari di Kecamatan Banuhampu dan Sungai Pua.

Selain itu untuk rata-rata TCR sub variable etika kerja aparatur nagari berada pada kategori "Sangat Tinggi" $(83,11 \%)$, bila dilihat dari kategori mean responden, maka dapat dijelaskan bahwa aparatur nagari yang mengikuti etika kerja berada di bawah rata-rata (mean) lebih besar dibanding mereka yang mengikuti etika kerja diatas rata-rata dengan perbandingan 52\%:48\%. Sehingga dapat disimpulkan bahwa aparatur nagari yang mengikuti etika kerja masih tergolong rendah dalam pengelolaan keuangan nagari di Kecamatan Banuhampu dan Sungai Pua. Sedangkan untuk rata-rata TCR variabel disiplin kerja aparatur nagari dalam pengelolan keuangan nagari berada pada kategori "Sangat Tinggi" $(83,11 \%)$, dan bila dilihat dari kategori mean responden, maka dapat dijelaskan 
bahwa aparatur nagari yang disiplin kerja berada diatas rata-rata lebih besar dibanding mereka yang disipin kerja dibawah rata-rata dengan perbandingan 51\%:49\%. Maka dapat disimpulkan disiplin kerja aparatur nagari dalam pengelolaan keuangan nagari di Kecamatan Banuhampu dan Sungai Pua tergolong tinggi.

Tabel 2. Deskripsi Variable Kinerja Pengelolaan Keuangan Nagari

\begin{tabular}{lcccc}
\hline \multirow{2}{*}{ Item pertanyaan } & \multirow{2}{*}{$\mathbf{N}$} & \multirow{2}{*}{ Mean/TCR } & \multicolumn{2}{c}{ Kategori mean responden } \\
\cline { 4 - 5 } & 75 & $3,33 / 83,33 \%$ & $36 / 48 \%$ & $39 / 52 \%$ \\
\hline Transparansi & 75 & $3,40 / 85,08 \%$ & $34 / 45 \%$ & $41 / 55 \%$ \\
Akuntabilitas & 75 & $3,35 / 83,83 \%$ & $36 / 48 \%$ & $39 / 52 \%$ \\
Partisipatif & 75 & $3,42 / 85,42 \%$ & $37 / 49 \%$ & $38 / 51 \%$ \\
Tertib dan Disiplin Anggaran & $\mathbf{7 5}$ & $\mathbf{3 , 3 8 / 8 4 , 4 2 \%}$ & $\mathbf{3 4 / 4 5 \%}$ & $\mathbf{3 7 / 5 5 \%}$ \\
\hline Rata-rata & & &
\end{tabular}

Berdasarkan Tabel 2 di atas dapat dijelaskan bahwa rata-rata pengelolaan keuangan nagari berada pada kategori "Sangat Tinggi" (84,42\%). Bila dilihat secara lebih rinci, maka aspek transparansi aparatur nagari berada pada kategori "Sangat Tinggi" (83,33\%), akuntabilitas aparatur nagari juga termasuk kategori "Sangat Tinggi" (85,08\%), partisipatif aparatur nagari termasuk kategori " Sangat Tinggi" (83,83\%), dan tertib dan disiplin anggaran berada pada kategori "Sangat Tinggi" $(85,42 \%)$. Selanjutnya bila dilihat dari kategori mean responden, maka dapat dijelaskan bahwa kinerja pengelolaan keuangan nagari yang berada di bawah rata-rata (mean) lebih besar persentasenya dibandingkan dengan pengelolaan keuangan nagari yang berada di atas rata-rata (mean) dengan perbandingan 55\% : 45\%. Sehingga dapat disimpulkan bahwa kinerja aparatur nagari dalam pengelolaan keuangan nagari masih tergolong rendah di Kecamatan Banuhampu dan sungai Pua.

Uji regresi linear berganda dilakukan untuk melihat dampak dari disiplin kerja terhadap kemampan kinerja aparatur nagari dalam pengelolaan keuangan nagari, Berikut adalah hasil uji analisis berganda dari data yang diperoleh dalam penelitian.

Tabel 3. Dampak Disiplin Kerja Secara Simultan terhadap kemampuan kinerja aparatur nagari dalam pengelolaan keuangan nagari

\begin{tabular}{|c|c|c|c|c|c|}
\hline \multicolumn{6}{|c|}{ Model Summary } \\
\hline Model & $\mathbf{R}$ & R Square & $\begin{array}{l}\text { Adjusted R } \\
\text { Square }\end{array}$ & $\begin{array}{l}\text { Std. Error of } \\
\text { the Estimate }\end{array}$ & Durbin-Watson \\
\hline 1 & $.598^{\mathrm{a}}$ & .358 & .340 & .33121 & 1.385 \\
\hline
\end{tabular}


Tabel 4. Hasil Uji Anova (F) dampak disiplin kerja terhadap kemampuan kinerja aparatur nagari dalam pengelolaan keuangan nagari

\begin{tabular}{llrrrrr}
\hline \multicolumn{7}{c}{ ANOVA $^{\mathbf{b}}$} \\
\multicolumn{1}{l}{ Model } & Sum of & & & & & \\
\hline 1 & Squares & Df & Mean Square & \multicolumn{1}{c}{ F } & Sig. \\
\hline & Regression & 4.402 & 2 & 2.201 & 20.062 & $.000^{\text {a }}$ \\
& Residual & 7.899 & 72 & .110 & & \\
& Total & 12.300 & 74 & & & \\
\hline
\end{tabular}

a. Predictors: (Constant), rata rata aturan kerja, rata-rata etika kerja

b. Dependent Variable: rata-rata pengelolaan

Pada tabel 3 di atas nilai Adjusted $R$ Square yang diperoleh dari analisis regresi adalah sebesar 0,340 . Artinya, secara simultan besarnya pengaruh variabel disiplin kerjayang mencakup dua sub variable (aturan kerja dan etika kerja) terhadap kinerja aparatur nagari dalam pengelolaan keuangan nagari adalah sebesar 34\% Sementara sebesar 66\% faktor yang mempengaruhi tidak diteliti dalam penelitian ini. Selain itu, bila diperhatikan hasil Uji Anova pada Tabel 4 di atas dapat pula dilihat bahwa hasil atau angka signifikansi pengaruh menunjukkan angka $0,000^{\mathrm{a}}$. Artinya, kebenaran kesimpulan hasil uji regresi ini dapat dipercaya sampai $100 \%$.

Selanjutnya, secara sendiri-sendiri dari dampak aspek aturan kerja dan etika kerja (sebagai sub variabel disiplin kerja) terhadap kinerja aparatur nagari dalam pengelolaan keuangan nagari di Kecamatan Banuhampu dan Sungai Pua, secara ringkas hasil pengujian regresi untuk menjawab rumusan masalah dijelaskan berdasarkan Tabel berikut ini.

Tabel 5. Pengaruh sub variabel aturan kerja dan etika kerja secara sendirisendiri terhadap kinerja aparatur nagari dalam pengelolaan keuangan nagari

\begin{tabular}{lcccc}
\hline \multicolumn{1}{c}{ Sub Variabel } & R & R Square & $\begin{array}{c}\text { Adjusted R } \\
\text { Square }\end{array}$ & Sig. \\
\hline Aturan kerja & $.501^{\mathrm{a}}$ & .251 & .241 & $.000^{\mathrm{a}}$ \\
Etika kerja & $.562^{\mathrm{a}}$ & .315 & .306 & $.000^{\mathrm{a}}$ \\
\hline
\end{tabular}

Berdasarkan tabel tersebut diketahui bahwa, nilai Adjusted $R$ Square untuk sub variabel aturan kerja adalah sebesar 0,241. Hal ini berarti bahwa pengaruh aturan kerja terhadap pengelolaan keuangan nagari sebesar $24,1 \%$. Selanjutnya nilai Adjusted $R$ Square untuk sub variabel etika kerja adalah sebesar 0,306. Berarti bahwa pengaruh etika kerja terhadap pengelolaan keuangan nagari sebesar 30,6\%. Selain itu, bila diperhatikan hasil uji Anova pada hasil atau angka signifikansi pengaruh menunjukkan angka $0,000^{\mathrm{a}}$ untuk dua sub-variabel. Ini berarti bahwa kebenaran kesimpulan hasil uji regresi ini dapat pula dipercaya sampai $100 \%$. 


\section{Pembahasan}

Hasil penelitian mengenai dampak disiplin kerja terhadap kemampuan kinerja aparatur nagari dalam pengelolaan keuangan nagari di Kecamatan Banuhampu dan Sungai Pua membuktikan disiplin kerja berdampak terhadap kemampuan kinerja aparatur nagari dalam pengelolaan keuangan nagar di Kecamatan Banuhampu dan Sungai Pua, baik secara simultan maupun secara sendiri-sendiri dari dua sub variabel disiplin kerja yaitu aturan kerja dan etika kerja. Secara bersama-sama dampakaturan kerja dan etika kerja terhadap kemampuan kinerja aparatur nagari dalam pengelolaan keuangan nagari di Kecamatan Banuhampu dan Sungai Pua menghasilkan angka signifikansi 0,000 dan nilai Adjust $R$ Square sebesar 0,340 sehingga dapat dikatakan bahwa kontribusinya adalah sebesar 34\% dan nilai $\mathrm{R}$ sebesar 0,598 maksudnya bahwa dampak variabel disiplin kerja terhadap kemampuan kinerja aparatur nagari dalam pengelolaan keuangan nagari di Kecamatan Banuhampu dan Sungai Pua sebesar 59,8\%. Dari penjelasan di atas dapat ditarik kesimpulan bahwa baik secara parsial maupun secara bersama-sama disiplin kerja memiliki dampak yang signifikan terhadap kemampuan kinerja aparatur nagari dalam pengelolaan keuangan nagari di Kecamatan Banuhampu dan Sungai Pua.

Selanjutnya hasil uji secara sendiri-sendiri dampak sub-variabel aturan kerja (X1), dan etika kerja (X2) terhadap pengelolaan keuangan nagari menghasilkan angka signifikansi masing-masing sebesar 0,000 dan nilai Adjust $R$ Square masing-masing sebesar 0,241(24,1\%) untuk aturan kerja, 0,306 (30,6\%) untuk etika kerja. Oleh karenanya dapat dikatakan bahwa kontribusi aturan kerja terhadap pengelolaan keuangan nagari sebesar 24\%, dan etika kerja sebesar 30\%.

Dengan memperhatikan hasil penelitian ini dapat dipahami bahwa hasil penelitian ini dapat membuktikan dan ikut memperkuat teori-teori dan temuan penelitian yang sudah ada, seperti dikemukakan oleh Putra et al (2016) yang mengatakan bahwa disiplin kerja merupakan salah satu aspek yang mempengaruhi kinerja karyawan. Kemudian menurut Leiden (dalam Putra et al, 2016) menyatakan bahwa dengan ditegakkannya disiplin kerja maka dapat mengatasi masalah kinerja yang buruk. Selain itu hasil dari penelitian Pangarso \& Susanti (2016) menunjukkan bahwa terdapat hubungan yang sangat erat antara disiplin kerja dengan kinerja pegawai, serta penelitian dari Mailiana, (2016) menyatakan terdapat pengaruh yang signifikan variable disiplin kerja terhadap kinerja pegawai. Hal ini berarti disiplin kerja yang baik tentu akan dapat memengaruhi kinerja seseorang menjadi lebih baik sehingga menjadikan sebuah organisasi juga lebih baik.

\section{Penutup}

Berdasarkan hasil penelitian dan pembahasan yang telah diuraikan sebelumnya, dapat disimpulkan bahwa untuk variabel disiplin kerja aparatur nagari sudah tergolong tinggi sedangkan untuk variabel kinerja aparatur nagari masih rendah. Hasil penelitian ini juga menunjukkan bahwa variable aturan kerja dan etika kerja memberikan dampak yang signifikan terhadap kemampuan kinerja aparatur nagari 
dalam pengelolaan keuangan nagari di Kecamatan Banuhampu dan Sungai Pua baik secara simultan maupun secara sendiri-sendiri.

Berdasarkan uraian dari hasil dan kesimpulan penelitian diatas, ada beberapa saran yang penulis kemukakan diantaranya:

1. Diharapkan agar seluruh nagari menerapkan dan menjalankan disiplin kerja aparatur pemerintahan nagari sesuai Peraturan Bupati Kabupaten Agam No 17 Tahun 2017 Tentang Disiplin Kerja Aparatur Pemerintahan Nagari demi meningkatkan kinerja.

2. Diharapkan Kepada seluruh aparatur nagari bisa meningkatkan kinerja terutama dalam pengelolaan keuangan nagari agar sebanding dengan kedisiplinan kerja yang telah dilakukan.

3. Diharapkan adanya pengawasan dari pemerintah daerah terkait dengan disiplin kerja dan kinerjadari aparatur nagari.

Dari penelitian yang penulis lakukan, penulis menyadari masih adanya kesalahan ataupun kelemahan dalam pelaksanaan penelitian ini, oleh karena itu penulis harapkan perbaikan penelitian oleh peneliti selanjutnya baik deri segi pelaksanaan penelitian maupun dari hasil penelitian agar melakukan penelitian yang lebih baik mendalam dengan melibatkan berbagai variabel lain yang mungkin juga dapat berpengaruh terhadap kinerja pengelolaan keuangan nagari di Kecamatan Banuhampu dan Sungai Pua.

\section{DAFTAR KEPUSTAKAAN}

\section{Referensi Dari Buku}

A.A. Anwar Prabu Mangkunegara.2001.Manajemen Sumber Daya Manusia , Bandun: Remaja Rosdakarya

BPKP (2015). Petunjuk Pelaksanaan Bimbingan \& Konsultasi Pengelolaan Keuangan Desa. Deputi Bidang Pengawasan Penyelenggaraan Keuangan Daerah

Hasibuan.2010.Manajemen Sumber Daya Manusia.Jakarta:Bumi Aksara

Mulyadi.(2015).Manajemen Sumber Daya Manusia . Jakarta:In Media

Syamsir.(2017). "Model Pembinaan Aparatur Pemerintahan Nagari Dalam Pengelolaan Keuangan Nagari Di Kabupaten Tanah Datar Provinsi Sumatera Barat". Laporan Penelitian:Universitas Negeri Padang.

\section{Referensi dari Jurnal}

Arianto, D. A. N. (2013). Pengaruh Kedisiplinan, Lingkungan Kerja dan Budaya Kerja Terhadap Kinerja Tenaga Pengajar. Jurnal Economia, 9, 191-200. https://doi.org/10.21831/ECONOMIA.V9I2.1809

B Baiyulis, S Syamsir, J Jumiati.2018. Pengaruh Kepuasan Kerja Terhadap Kinerja Perangkat Nagari Dalam Pengelolaan Keuangan Nagari di 
Kecamatan Sungai Tarab dan Salimpaung. Journal of Education on Social Science (JESS) 2 (2), 73-84

F Fatmaliza, S Syamsir, J Jumiati.2018. Kontribusi Pengalaman Kerja Terhadap Kinerja Perangkat Nagari dalam Pengelolaan Keuangan Nagari di Kabupaten Tanah Datar. Journal of Education on Social Science (JESS) 2 (2), 85-98

Husain, B. A. (2018). Pengaruh Motivasi Kerja dan Disiplin Kerja Terhadap Kinerja Karyawan Pada Pt Indah Kiat Pulp \& Paper. Jurnal Ekonomi Efektif, $1(1), 24-42$.

Liyas, J. N., \& Primadi, R. (2017). Pengaruh disiplin kerja terhadap kinerja karyawan pada bank perkreditan rakyat. Al Masraf: Jurnal Lembaga Keuangan Dan Perbankan, 2(1), 1-10. https://doi.org/10.1016/j.nanoen.2012.08.008

Mailiana. (2016). Pengaruh disiplin kerja terhadap kinerja pegawai dinas pengelolaan pasar kota bajarmasin. Jurnal Ekonomi Manajemen, 10(1), 123134.

Oktaviani, Y. (2018). Kontribusi Kecerdasan Emosional dan Kecerdasan Sosial Terhadap Kinerja Pegawai Pada Organisasi Perangkat Daerah Kabupaten Tanah Datar Yeyen Oktaviani, 2(2), 147-158.

Pangarso, A., \& Susanti, P. I. (2016). Pengaruh Disiplin Kerja Terhadap Kinerja Pegawai Di Biro Pelayanan Sosial Dasar Sekretariat Daerah Provinsi Jawa Barat. Jurnal Manajemen Teori Dan Terapan Tahun, 9(2), 145-160. https://doi.org/10.1108/eb045146

Permatasari, J. A., \& Mayowan, M. A. M. Y. (2015). Pegaruh Disiplin Kerja dan Motivasi Kerja Terhadap Prestasi Kerja Karyawan. Jurnal Administrasi Bisnis, 25(1), 7-9.

Permatasari, K., Pratiwi, R. N., \& Suwondo. (2013). Otonomi Desa Dalam Pengelolaan Dana Asset Desa. Jurnal Administrasi Publik, 1(6), 1213-1219.

Putera, R. E. (2016). Pengelolaan Keuangan Daerah Yang Transparan Di Kabupaten Tanah Datar Dalam Melaksanakan Desentralisasi Fiskal. Sosiohumaniora, 18(3), 261-269. https://doi.org/10.2307/638116

Putra, W. I., Suwendra, W., \& Bagia, W. (2016). Pengaruh Tingkat Pendidikan dan Disiplin Kerja Terhadap Kinerja Karyawan. E-Journal Bisma Universitas Pendidikan Ganesha Jurusan Manajemen, 4(1).

Z Azhari, S Syamsir.2012. Pengaruh Kepuasan Kerja dan Lingkungan Kerja terhadap Motivasi Kerja PNS Sekretariat DPRD Sumatera Barat. TINGKAP 8 (1), 93-110

\section{Referensi Dari Peraturan Pemerintah}

Undang -Undang Nomor 23 Tahun 2014 Tentang Pemerintahan Daerah 
Undang-Undang Nomor 6 Tahun 2014 Tentang Desa

Permendagri Nomor 113 Tahun 2014 Tentang Pengelolaan Keuangan Desa

\section{Referensi dari internet}

Antara sumbar.2017. "agam nilai delapan nagari tentang pengelolaan keuangan nagari” .https://sumbar.antaranews.com/berita/215530/agam-nilai-delapannagari-tentang-pengelolaan-keuangan". Diakses sabtu 11 November 2017.

Antara sumbar .2017."HPN 2018 - Tim Provinsi Nilai Pengelolaan Dana Desa NagariTigoBalaiAgam" .https://sumbar.antaranews.com/berita/217232/hpn -2018--tim-provinsi-nilai-pengelolaan-dana-desa-nagari-tigo-balai-agam.

Diakses rabu 13 